\title{
Path Analysis on the Relationship Between Bio-psychosocial Factors During Gestational Period and Birthweight, Stimulation and Development in Children Aged 1-3 Years in Salatiga
}

\author{
Vistra Veftisia'), Didik Tamtomo²), Muhammad Akhyar 3) \\ 1)Faculty of Health Sciences, Universitas Ngudi Waluyo, Ungaran, Central Java \\ ${ }^{2)}$ Faculty of Medicine, Universitas Sebelas Maret \\ 3)Faculty of Teaching and Education, Universitas Sebelas Maret
}

\begin{abstract}
Background: Bio-psychosocial condition during gestational period, such as maternal nutritional status, stress, education, and family income, may have significant impact on fetal growth and development. The purpose of this study was to examine the relationship between bio-psychosocial factors during gestational period and birthweight, stimulation and development in children aged 13 years in Salatiga, using path analysis model.

Subjects and Method: This was an analytic observational study with a case control design. A sample of 120 children aged 1-3 years was selected by fixed disease sampling. The dependent variable was child development. The independent variables were maternal education, family income, maternal stress, maternal nutritional status, birthweight, and stimulation. The data were collected by questionnaire and analyzed by path analysis run on STATA 13 .

Results: Child development was directly increased with birthweight $\geq 2.500 \mathrm{~g}(\mathrm{~b}=0.96$; 95\%CI= -0.15 to $1.94 ; \mathrm{p}=0.054)$ and good stimulation $(\mathrm{b}=0.43 ; 95 \% \mathrm{CI}=-0.30$ to $0.89 ; \mathrm{p}=0.067)$. Child development was directly affected by family income, maternal education, maternal stress, maternal MUAC, and stimulation.

Conclusion: Child development is directly increased with birthweight $\geq 2.500 \mathrm{~g}$ and good stimulation. Child development is directly affected by family income, maternal education, maternal stress, maternal MUAC, and stimulation.
\end{abstract}

Keywords: bio-psychosocial, gestational period, birthweight, stimulation, development

Correspondence:

Vistra Veftisia. Faculty of Health Sciences, Ngudi Waluyo University, Ungaran, Central Java. Email: chan_viez@yahoo.com

\section{BACKGROUND}

Unfavorable conditions during pregnancy, such as nutritional deficiencies, maternal stress, inadequate exercise, and inadequate prenatal care, can lead to an inadequate development of the fetus. The development of an unfavorable fetus is a health risk in later life (Wilkinson and Marmot, 2003 in Murti 2011).

Development is the increasing ability (skill) in the structure and function of the body more complex in a regular pattern and can be called as a result of the process of maturation (Soetjiningsih and Gde Ranuh, 2014).

The child's future quality is determined by optimal child development and growth. Detection, stimulation, and intervention in children should be done early. Motor ability and intelligence of each child is different. Good motor development in children will make children more adapt and adjust to school environment. The ability to adapt to encourage children more able to make friends with others while doing activities. Normal motor development allows the child to play or mingle with his 
Journal of Epidemiology and Public Health (2016), 1(3): 157-167

https://doi.org/10.26911/jepublichealth.2016.01.03.02

peers, while the abnormal will hinder the child to get along with his peers even he will be isolated or become a marginalized child (Marmi and Rahardjo, 2012).

According to Adriana (2013), factors affecting growth and development in children are internal factors, external factors (prenatal, delivery, and postpartum factors). Prenatal factors include nutrition, mechanics, toxins, endoctrin, radiation, psychological mothers, while postpartum factors include nutrition, psychological, social environment, and stimulation.

The results of interviews with the midwife coordinator of public health centers in the city said that it does not carry out monitoring of child development because it is more focus on implementing growth monitoring. The impact there is no data report on the problem of child development in Salatiga City. The researcher chose the work area of Tegalrejo Health Center and Sidorejo Kidul Town of Salatiga as a research place by looking at data of problem of high nutritional status in the region.

Children under three years (toddlers) are very energetic and active, full of boundless energy, enthusiastic and curious. Although the rate of growth slows down during this stage, changes in development are important. Improved motor skills allow toddlers to move on their own and explore the environment. Rapid developments in speech and language play a role in improving the ability to think and learn more complex (Allen and Marotz, 2010).

Many questions about child development have not been answered until now. For example what exactly drives the process of biological, cognitive development, and how things that happen in infancy affect childhood.
By looking at the problems of child development and rstudy on factors related to the development of children described by using models of bivariate or multivariate analysis but not yet analyzed gradually to explain the direct and indirect consequences associated with child development, the researcher conducted a research titled " Biopsychosocial Factors Gestational Period with Birth Weight, Stimulation with the development of 1-3 years of age in Salatiga City ".

\section{SUBJECTS AND METHOD}

This was an analytic observasional study with a case control design. The study was conducted in Salatiga, Central Java, from October 4 to November 2, 2016. Exogenous variables are maternal education during pregnancy and mother education now. Endogenous variables are family income during pregnancy, current family income, stress in pregnancy, nutritional status of pregnant women, birth weight, and child development.

The target population is mother and toddler in Salatiga City area. Population of study source is mother and toddler in working area of Sidorejo Kidul Public Health Center and Tegalrejo Public Health Center, Salatiga City. A sample of 120 children aged 1-3 years were selected by fixed disease sampling. The data were collected by medical record and questionnaire. The data were analyzed by path analysis run on Stata 13 .

\section{RESULTS \\ 1. Sample Characteristics}

The results of the study describing the characteristics of the study subjects are shown in Table 1. 
Table 1. Sample Characteristics

\begin{tabular}{lcc}
\hline \multicolumn{1}{c}{ Characteristics } & $\mathbf{n}$ & $\mathbf{\%}$ \\
\hline Maternal age & 2 & $1.7 \%$ \\
$<20$ years & 104 & $86.7 \%$ \\
$20-35$ years & 14 & $11.7 \%$ \\
$\geq 35$ years & & \\
Maternal occupation & 88 & $73.3 \%$ \\
Unemployed & 32 & $26.7 \%$ \\
Employed & & \\
Parity & 57 & $47.5 \%$ \\
$<2$ & 63 & $52.5 \%$ \\
$\geq 2$ & & $59.2 \%$ \\
Toddler age & 71 & $40.8 \%$ \\
$12-24$ months & 49 & $19.2 \%$ \\
$25-36$ months & & $80.8 \%$ \\
Number of ANC visit & 23 & \\
$<8$ times & 97 & $4.2 \%$ \\
$\geq 8$ times & & $95.8 \%$ \\
Gestational age & 5 & $81.7 \%$ \\
$<36$ months & 115 & $18.3 \%$ \\
\hline 36 months & & \\
Exclusive breastfeeding & 98 & 22 \\
Yes & & \\
\hline
\end{tabular}

Table 2. Frequency distribution of study variables

\begin{tabular}{llcc}
\hline \multicolumn{1}{c}{ Variable } & \multicolumn{1}{c}{ Criteria } & Frequency & (\%) \\
\hline Education of pregnant & <Senior High School & 28 & 23.3 \\
women & & & \\
& 2Senior High School & 92 & 76.7 \\
Family income & <Minimum regional wage & 37 & 30.8 \\
\multirow{2}{*}{ Stress during pregnancy } & $\geq$ Minimum regional wage & 83 & 69.2 \\
& No stress & 83 & 69.2 \\
Maternal nutritional status & Stress & 37 & 30.8 \\
& Maternal MUAC < 23.5 cm & 22 & 18.3 \\
Current maternal education & Maternal MUAC $\geq 23.5 \mathrm{~cm}$ & 98 & 81.7 \\
\multirow{2}{*}{ Current family income } & <Senior High School & 27 & 22.5 \\
& $\geq$ Senior High School & 93 & 77.5 \\
Birth weight & <Minimum regional wage & 33 & 27.5 \\
\multirow{2}{*}{ Stimulation } & $\geq$ Minimum regional wage & 87 & 72.5 \\
\multirow{3}{*}{ Development of toddlers } & <2,500 g & 7 & 5.8 \\
& $\geq 2,500$ g & 113 & 94.2 \\
& Good & 64 & 53.3 \\
& Not good & 56 & 46.7 \\
& Deviate & 39 & 32.5 \\
\hline
\end{tabular}

Sample characteristics in Table 1 show the description in the form of classification, frequency and percentage that of 120 mothers majority were at age 20-35 years (86.7\%) and unemployed mother (73.3\%). Number of children $\geq 2(52.5 \%)$, children aged 12-24 months (59.2\%), ANC $\geq 8$ times $(80.8 \%)$, gestational age at deli- 
Journal of Epidemiology and Public Health (2016), 1(3): 157-167

https://doi.org/10.26911/jepublichealth.2016.01.03.02

very $\geq 36$ months (95.8\%), and exclusive breastfeeding (81.7\%).

\section{Univariate Analysis}

Table 2 shows results of univariate analysis. Table 2 shows that majority of mothers had education $\geq$ senior high school (76.7\%), family income $\geq$ minimum regional wage (69.2\%), (72.5\%), low stress in pregnancy (69.2\%), and maternal MUAC $\geq 23.5 \mathrm{~cm}$ (81.7\%). Mostly, children had birth weight $\geq 2,500$ g (94.2\%).

\section{Path Analysis}

The results of path analysis model are shown in Figures 1 and 3. Table 3 shows the results of calculations using STATA 13.

Normal child development was directly and positively associated with birthweight $\geq 2,500 \mathrm{~g}(\mathrm{~b}=0.96 ; 95 \% \mathrm{CI}=-0.15$ to $1.94 ; \mathrm{p}=0.054)$ and good stimulation $(\mathrm{b}=$ $0.43 ; 95 \% \mathrm{CI}=-0.30$ to $0.89 ; \mathrm{p}=0.067)$.

Family income was positively associated with maternal education during pregnancy $\geq$ Senior high school $(b=1.51$; 95\% $\mathrm{CI}=0.61$ to $2.39 ; \mathrm{p}=0.001)$ and current maternal education $\geq$ Senior high school $(b=1.20 ; 95 \% \mathrm{CI}=0.50$ to $1.90 ; \mathrm{p}=$ 0.001).

Maternal stress reduced with high maternal income during pregnancy ( $\geq \mathrm{Rp} 1,450,000)$ and it was statistically significant $(b=-1.34 ; 95 \% \mathrm{CI}=-2.17$ to -0.51 ; $\mathrm{p}=0.002)$.

Maternal MUAC $\geq 23.5 \mathrm{~cm}$ increased with maternal income during pregnancy $\geq \mathrm{Rp} 1,450,000(\mathrm{~b}=1.02 ; 95 \% \mathrm{CI}=-0.11$ to 2.06; $\mathrm{p}=0.052)$ and maternal education during pregnancy $\geq$ Senior high school $(b=$ $0.39 ; 95 \% \mathrm{CI}=-0.68$ to $1.46 ; \mathrm{p}=0.475$ ).

Maternal MUAC $\geq 23.5 \mathrm{~cm}$ decreased with high stress $(b=-0.43 ; 95 \% \mathrm{CI}=-1.45$ to $0.58 ; p=0.405)$.

Normal birthweight $(\geq 2,500 \quad \mathrm{~g})$ increased with maternal MUAC $\geq 23.5 \mathrm{~cm}$ $(b=3.59 ; 95 \% \mathrm{CI}=1.41$ to $5.78 ; \mathrm{p}=0.001)$.

Good stimulation of child development increased with current maternal education $\geq$ Senior high school $(b=0.65 ; 95 \%$ $\mathrm{CI}=-0.31$ to $1.56 ; \mathrm{p}=0.150$ ) and current income $\geq \operatorname{Rp~1,450,000~(b=0.47;95\% ~CI=~-~}$ 0.38 to $1.31 ; \mathrm{p}=0.279$ ).

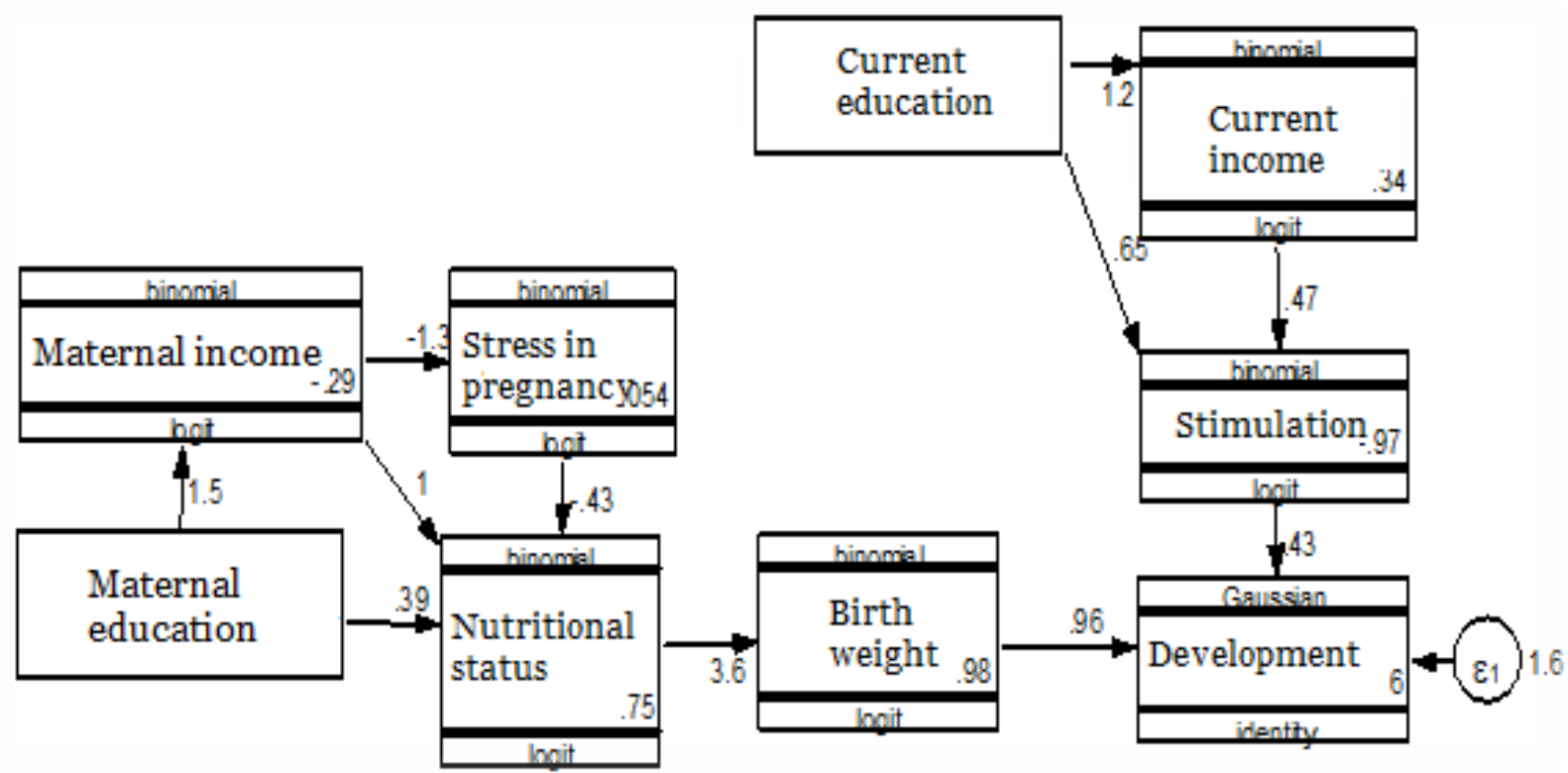

Figure 1. Path analysis model with estimation 
Table 3. The results of path analysis model on the biopsychosocial factors associated with development of children aged 1-3 years

\begin{tabular}{|c|c|c|c|c|c|c|}
\hline \multirow[b]{2}{*}{$\begin{array}{l}\text { Dependent } \\
\text { Variable }\end{array}$} & & \multirow[b]{2}{*}{ Independent Variable } & \multirow{2}{*}{$\begin{array}{c}\text { Path } \\
\text { Coef. } \\
\text { (b) }\end{array}$} & \multicolumn{2}{|c|}{$95 \% \mathrm{CI}$} & \multirow[b]{2}{*}{$\mathbf{p}$} \\
\hline & & & & $\begin{array}{l}\text { Lower } \\
\text { limit }\end{array}$ & $\begin{array}{l}\text { Upper } \\
\text { Limit }\end{array}$ & \\
\hline \multicolumn{7}{|l|}{ Direct Effect } \\
\hline \multirow[t]{2}{*}{ Child development } & $\leftarrow$ & Birthweight $\geq 2,500 \mathrm{~g}$ & 0.96 & -0.15 & 1.94 & 0.054 \\
\hline & $\leftarrow$ & Good stimulation & 0.43 & -0.30 & 0.89 & 0.067 \\
\hline \multicolumn{7}{|l|}{ Indirect Effect } \\
\hline Family income & $\leftarrow$ & $\begin{array}{l}\text { Maternal education during } \\
\text { pregnancy } \geq \text { Senior high school }\end{array}$ & 1.51 & 0.61 & 2.39 & 0.001 \\
\hline Family income & $\leftarrow$ & $\begin{array}{l}\text { Current maternal education } \\
\geq \text { Senior high school }\end{array}$ & 1.20 & 0.50 & 1.90 & 0.001 \\
\hline Stress & $\leftarrow$ & $\begin{array}{l}\text { Maternal income during } \\
\text { pregnancy } \geq R p 1,450,000\end{array}$ & -1.34 & -2.17 & -0.51 & 0.002 \\
\hline \multirow[t]{3}{*}{ Maternal MUAC } & $\leftarrow$ & $\begin{array}{l}\text { Maternal income during } \\
\text { pregnancy } \geq R p 1,450,000\end{array}$ & 1.02 & -0.11 & 2.06 & 0.052 \\
\hline & & $\begin{array}{l}\text { Maternal education during } \\
\text { pregnancy } \geq \text { Senior high school }\end{array}$ & 0.39 & -0.68 & 1.46 & 0.475 \\
\hline & $\leftarrow$ & High stress & -0.43 & -1.45 & 0.58 & 0.405 \\
\hline Birth weight & $\leftarrow$ & Maternal MUAC $\geq 23.5 \mathrm{~cm}$ & 3.59 & 1.41 & $5 \cdot 78$ & 0.001 \\
\hline \multirow[t]{2}{*}{ Stimulation } & & $\begin{array}{l}\text { Current education } \geq \text { Senior } \\
\text { high school }\end{array}$ & 0.65 & -0.31 & 1.56 & 0.150 \\
\hline & & $\begin{array}{l}\text { Current income } \geq R p \\
1,450,000\end{array}$ & 0.47 & -0.38 & 1.31 & 0.279 \\
\hline $\begin{array}{l}\text { N Observation }=12 \\
\text { Log likelihood }=55\end{array}$ & $\begin{array}{l}0 \\
7.64\end{array}$ & & & & & \\
\hline
\end{tabular}

\section{DISCUSSION}

1. The relationship between birth weight and child development

There is a direct relationship between birth weight and child development but statistically only close to significant. A study by Chapakia (2016) supported with the results of this study that birth weight affect the development of children.

The study of Carrasco et al. (2016) also supports the results of studies of infants with short stature having low mean language ability and average birth weight infants associated with psycho-motor development.

The results of the study found that there was a relationship between birth weight and child development. This study also supported by Sally et al. (2014) that nutrition and stimulation interventions provide benefits for child development.

\section{The relationship between maternal} stimulation and child development

There is a direct relationship between birth weight and development but statistically significant.

A study Yousafzai et al. (2016) stated that children who received responsive stimulation had significantly higher cognition, language, and motor skills than children who did not receive responsive stimulation.

However, the results of maternal stimulation and child development are only significantly approximated as many things affect the child's development. This is also supported by studies of Sally et al. (2014); Carrasco et al., (2016) that the provision of nutritional interventions and birth weight of children is related to child development. 
Journal of Epidemiology and Public Health (2016), 1(3): 157-167

https://doi.org/10.26911/jepublichealth.2016.01.03.02

\section{The relationship between mother education and family income}

There is a direct relationship of maternal education to family income and is statistically significant.

The results of study supported Maryanti and Septikasari (2009) that in education there is a learning process so that individuals are actively developing the potential and skills required. Such skills can be used to obtain decent work, so that socioeconomic and educational conditions relate to one another.

A study by Dwiandana and Setiawina (2013), also mentions that education and occupation have a positive and partially significant effect on household income.

\section{The relationship between family income during pregnancy and stress in pregnancy}

There is a direct relationship of family income to stress in pregnancy and is statistically significant.

The results are supported by Pinel (2009) that when the body is exposed to threats, the result is a set of changes in physiological changes that are generally called stress responses.

Research Brittain et al. (2015), also supports the results of research of pregnant women who have BDI-II scores (measuring stress) showed depression, one of which is influenced by low socioeconomic.

\section{The relationship between family income during pregnancy and nutritional status of pregnant women}

There is a direct correlation of family income with nutritional status of pregnant women but only statistically significant. The results of the study were supported by Almatsier et al. (2011), which states that family income is associated with poverty, lack of hygiene, health problems and the fulfillment of nutritional needs of pregnant women as food intake during pregnancy determines the nutritional status of pregnant women.

The results were also supported by the study of Liu et al. (2015), with the results of household income having a positive relationship with folic acid intake of pregnant women.

The result of study of family income relation with nutritional status of pregnant mother approaching significant is predicted because nutritional status of pregnant mother there are several factors influencing it. Supported research Ausa and Jafar (2013), with the results of research that there is no significant relationship between family income with SEZ events.

\section{The relationship between maternal education during pregnancy and maternal nutritional status}

There is a direct relationship between maternal education with nutritional status of pregnant women but not statistically significant.

Maternal education affects the attitude of women to their health, the higher the education the easier to receive information so that more knowledge is owned. Education is needed to obtain information such as health supporting things, so as to improve the quality of life especially food that must be consumed to meet the nutritional needs during pregnancy (Maryanti and Septikasari, 2009; Maulina (2010).

The results of research supported by Liu et al., (2015) that the level of education has a positive relationship with folic acid intake of pregnant women. The result of research about mother education relation on pregnant mother's nutritional status which is not significant allegedly caused by other factors influencing the nutritional status the pregnant mother. The results of Ausa and Jafar (2013) showed no signifi- 
cant relationship between education and Chronic Energy Conscience events.

\section{The relationship of stress in preg-} nancy and nutritional status of pregnant women

There is a direct relationship of stress in pregnancy to the nutritional status of pregnant women but statistically insignificant.

The result of study supported by Kalat (2010) that the stress that occurs in a long time will trigger the secretion of cortisol hormone that increases blood sugar and increase metabolism. These changes have the reward of decreasing immune system activity.

The result of study on the relationship of stress in pregnancy with nutritional status of the pregnant mother which is not significant is suspected because of nutritional status the pregnant mother also there are some factors influencing it. Handayani and Budianingrum (2011) research indicate that birth spacing, education, and knowledge of mothers are related to nutritional status of pregnant women.

\section{The relationship between nutritio- nal status of pregnant women and birth weight}

There is a direct relationship between nutritional status of pregnant women with birth weight and statistically significant. The results of the study were supported by Adriani and Wirjatmadi (2012) that pregnant women with Chronic Energy Deficiency will be at risk of delivering babies with low birth weight (LBW). LBW infants have an increased risk of death, malnutrition, developmental disorders and developmental aberrations.

Study Yongky et al., (2009), also supports with the results of study that the nutritional status of pregnant women affect birth weight.

\section{The relationship between current maternal education and mother's stimulation}

There is a direct relationship between maternal education with maternal stimulation but is not statistically significant.

The results of research supported by Marmi and Raharjo (2012) which states that high maternal education status will be easier to receive direction to improve child development. A study by Ariani (2013) supports the results of this study that there is a relationship between maternal education with the ability to stimulate gross motor development.

The results of research on maternal education relationship with mother stimulation that is not significant are possible because of stimulation by mother there are several factors that influence. Ariani (2013) states that maternal stimulation is not only related to maternal education but there is also a relationship with the mother's age, work, and socio-economic family.

10. The relationship between current family income and maternal stimulation

There is a direct relationship of family income with maternal stimulation although statistically insignificant.

A study by Romeuli and Vindari (2012) indicates that low family incomes make mothers and children have limitations to play outside of their environment, thus affecting their outlook and narrowing the scope of their association.

The result of research also supported by Ariani (2013) research, with the result of the correlation between socioeconomic condition with the ability of stimulation of gross motor development of baby aged 1-12 months.

The result of the research of family income relation with unimportant mother stimulation is assumed to be influenced by 
Journal of Epidemiology and Public Health (2016), 1(3): 157-167

https://doi.org/10.26911/jepublichealth.2016.01.03.02

other factors, as mentioned by Ariani (2013) that maternal stimulation is not only related to the family social economy but also related with age mother, work, and education.

11. The relationship between maternal education during pregnancy and child development through nutritional status and birth weight

There is an indirect relationship between education and child development through nutritional status and birth weight.

The results of rstudy are supported by Marmi and Rahardjo (2012), stating that parental education status, high-education families will more easily receive direction to improve the growth and development of children.

The results of this study also supported the study of Demelesh et al. (2015) that low education affects the pattern of nutritional intake, pregnancy care, and the risk of giving birth to LBW infants. The study of Sally et al. (2014), Carrasco et al., (2016) also supports the results of studies of child birth weight associated with child development.

12. The relationship between family income during pregnancy and child development through nutritional status and birth weight

There was an indirect relationship between family income and child development through nutritional status and birth weight.

Almatsier et al. (2011) states that low socioeconomic conditions affect the course of pregnancy. The effect appears to be greater likelihood of maternal mortality during childbirth or infant death at birth, or low birth weight (LBW) infants.

Demelesh et al., (2015), stated that families with low incomes provide the risk of giving birth to low birth weight infants. The study of Sally et al. (2014), Carrasco et al. (2016) also supports the results of this study.

13. The relationship between stress in pregnancy and child development through nutritional status and birth weight

There is an indirect relationship between stress in pregnancy with the development of the child through the nutritional status of pregnant women and birth weight.

The results of research supported by Cheng et al. (2016); Christine et al., (2012) with the results of research that the incidence of stress during pregnancy whether derived from physical activity, financial burden, physical violence or social environment can increase the risk for low birth weight, which is a risk factor that harms the mother and child.

Van den Bergh et al. (2004) supported the results of the study with 14 independent prospective studies showing the relationship between maternal stress in pregnancy/ stress and cognitive, behavioral, and emotional problems in children.

14. The relationship between nutritio-

nal status and development through birth weight

There is an indirect relationship between nutritional status and child development through birth weight. The results of this study was supported Yongky et al., (2009) that the nutritional status of pregnant women affect birth weight. According to Carrasco et al., (2016) the baby's birth agency is associated with future childhood development.

\section{The relationship between mater- nal education now and child deve- lopment through maternal stimu- lation}

There was an indirect relationship between education and child development through maternal stimulation. 
The results of the study were supported by Santrock (2007) that a high level of education causes a person to have more access to information, thus providing different opportunities for the child to get stimulated.

Ariani (2013) shows there is a relationship between maternal education with the ability to stimulate rough motor development of infants aged 1-12 months. Yousafzai et al., (2016) also stated that children who received responsive stimulation had significantly higher cognition, language, and motor skills than children who did not receive responsive stimulation.

\section{The relationship between current family income and child develop- ment through maternal stimula- tion}

There is an indirect relationship between family income and child development through maternal stimulation. Romauli and Vindari (2012), Santrock (2007) stated that the work of a person with a higher status leads to more access than others and children who get stimulation or stimulation will improve their development.

The results of study also supported by Ariani (2013) that there is a relationship between socio-economic conditions with the ability of stimulation of gross motor development. Yousafzaietal study (2016) showed that children who received responsive stimulation had significantly higher cognitive development, language, and motor skills than children who did not receive responsive stimulation.

The results of this study can be concluded that the development of children affected by birth weight and stimulation. Birth weight is influenced by maternal education, family income, stress in pregnancy, and nutritional status of pregnant women. Stimulation is influenced by maternal education, family income.

\section{REFERENCE}

$\overline{\text { Adriana D (2013). Tumbuh Kembang dan }}$ Terapi Bermain pada Anak. Jakarta: Salemba Medika.

Allen KE, Marotz LR (2010). Profil Perkembangan Anak Pra Kelahiran Hingga Usia 12 tahun Edisi Kelima. Jakarta: Indeks.

Almatsier S, Soetardjo S, dan Soekatri M (2011). Gizi Seimbang dalam Daur Kehidupan. Jakarta: Gramedia Pustaka Utama.

Ariani D (2013). Hubungan karakteristik ibu dengan kemampuan stimulasi perkembangan motorik kasar bayi usia 1-12 bulan di Gampong Rukoh Kecamatan Syiah Kuala Kota Banda Aceh 2013.

Ausa ES, Jafar N, Indriasari R (2013). Hubungan pola makan dan status sosial ekonomi dengan kejadian KEK pada ibu hamil di Kabupaten Gowa tahun 2013.

Brittain K, Myer L, Koen N, Koopowitz S, Donald KA, Barnett W, Zar HJ (2015). Risk Factors for Antenatal Depression and Associations with Infant Birth Outcomes: Results From a South African Birth Cohort Study. Paediatric and Perinatal Epidemiology, 29(6): 505-514.

Carrasco QMR, Ortiz HL, Roldan AJA, Chavez VA (2016). Malnutrition And Cognitive Development If Infants In Rural Marginalized Areas In Mexico. Gaceta sanitaria/SESPAS.30(4):3047.

Cheng E, Park H, Wisk L, Mandell K, Wakeel F, Litzelman K, Chatterje D, and Witt W (2016). Examining the link between women's exposure to stressful life events prior to conception and infant and toddler health: the role of birth weight. Journal Epidemiol Community, 70:245-252. 
Christine DS, Lynlee T (2012). Anxiety, depression and stress in pregnancy: implications for mothers, children, research, and practice. Curr Opin Psychiatry; 25(2): 141-148.

Demelash H, Motbainor A, Nigatu D, Gashaw K, Melese A (2015). Risk factors for low birth weight in Bale zone hospitals, South-East Ethiopia: a case-control study. BMC pregnancy and childbirth, 15(1):264.

Dwiandana PA, Setiawina D (2013). Pengaruh Umur, Pendidikan, Pekerjaan Terhadap Pendapatan Rumah Tangga Miskin di Desa Bebandem. E-Jurnal Ekonomi Pembangunan Universitas Udayana, 2(4):173-180.

Handayani S, Budianingrum S (2011). Analisis faktor yang mempengaruhi kekurangan energi kronis pada ibu hamil di wilayah Puskesmas Wedi Klaten. Jurnal Involusi Kebidanan, 1(1):42-60.

Kalat JW (2010). Biopsikologi Biological Psychology Edisi 9. Jakarta: Salemba Humanika.

Liu FL, Zhang YM, Parés GV, Reidy KC, Zhao WZ, Zhao A, Chen C(2015). Nutrient Intakes of Pregnant Women and their Associated Factors in Eight Cities of China: A Cross-sectional Study. Chinese Medical Journal, 128(13): 1778-1786.

Marmi, Raharjo K (2012). Asuhan Neonatus, Bayi, Balita, dan Anak Pra Sekolah. Yogyakarta. Pustaka Pelajar.

Maryanti D, Septikasari M (2009). Kesehatan Reproduksi Teori dan Praktikum. Yogyakarta: Nuha Medika.

Murti B (2011). Kesehatan Anak dan Epidemiologi Sepanjang Hayat. Jurnal Kedokteran Indonesia, 2(1).
Pinel JPJ (2009). Biopsikologi Edisi Ketujuh. Yogyakarta: Pustaka Belajar

Romauli S, Vindari AV (2012). Kesehatan Reproduksi untuk Mahasiswi Kebidanan.Yogyakarta: Nuha Medika.

Sally MGM, Lia CHF, Rose MCK, Susan W (2014). Effects integrated child development and nutrition interventions on development and nutritional status. Annals of The New York Academy of Science. 1308:11-32.

Santrock JW (2007). Perkembangan Anak Edisi Kesebelas. Jakarta: Erlangga.

Soetjiningsih, Gde Ranuh IGN (2014). Tumbuh Kembang Anak edisi 2. Jakarta: EGC.

Van den Bergh BR, Mulder EJ, Mennes M, dan Glover V (2005). Antenatal maternal anxiety and stress and the neurobehavioural development of the fetus and child: links and possible mechanisms. A review. Neuroscience \& Biobehavioral Reviews, 29(2): 237258.

Yongky, Hardinsyah, Gulardi, Marhamah. (2009). Status Gizi Awal Kehamilan dan Pertambahan Berat Badan Ibu Hamil Kaitannya dengan BBLR. Jurnal Gizi dan Pangan, 4(1):8-12.

Yousafzai AK, Obradovic J, Rasheed MA, Rizvi A, Portilla XA, Tirado-Strayer N, Memon U (2016). Effects of responsive stimulation and nutrition interventions on children's development and growth at age 4 years in a disadvantaged population in Pakistan: a longitudinal follow-up of a cluster randomised factorial effectiveness trial. The Lancet Global Health, 4(8), e548-e558. 